\title{
Developing Beach Ball Group Investigations Cooperative Learning Model to Improve Social Skill in Speaking Course
}

\author{
Agus Darmuki $^{1}$, Ahmad Hariyadi ${ }^{2}$ and Nur Alfin Hidayati ${ }^{3}$ \\ \{agus_darmuki@yahoo.co.id ${ }^{1}$, ahmadhariyadi31@yahoo.co.id ${ }^{2}$, \\ nikidanajwasalsabila@yahoo.com ${ }^{3}$ \} \\ 1,2,3 IKIP PGRI Bojonegoro, Indonesia
}

\begin{abstract}
Speaking course at higher education has worthy responsibility and becomes pivotal foundation for the development of personal communication, intellectual, emotional, cultural, and social. This research aimed at developing Beach Ball Group Investigation (BBGI) cooperative learning model to improve social skill and investigating the effectiveness of this model in speaking course. The research design was Research and Development ( $\&$ \&). The data were collected through questionnaire, interview, assessment sheet of social skill observation, and multiple choices. The data analysis employed t-test and n-gain to test the product effectiveness. The research result concluded that BBGI cooperative learning model was effective in improving student's social skill. It was indicated by coefficient value of $t_{\text {calculation }}$ which was greater than that of table, as well as the difference between pre-test and post-test (n-gain) which was in good category.

Keywords: Beach Ball Investigation Group, Social Skill, Cooperative Learning, Model, Development, Speaking.
\end{abstract}

\section{INTRODUCTION}

Speaking course at higher education has worthy responsibility and becomes pivotal foundation for the development of personal communication, intellectual, emotional, cultural, and social. Students are expected to develop responsibility in communicating, thinking, behaving, and acting. In addition, a speaking course functions for developing speaking abilities in terms of knowledge, value, attitude, and social skills in daily life. It also aims at growing pride and love to society development from the previous to the recent era. The use of a learning model during the teaching and learning process is very beneficial to lecturers and students [24]. To lecturers, a learning model can create an active, interactive, and motivated learning activity to express their ideas based on the learning materials being discussed. By a learning model, both students and lecturers can achieve the learning objectives. The goal of classroom learning is emphasized on the student's behavior or performance as the output. It also aims at showing that students have conducted learning activity. The duties of learning are to educate and guide students in learning as well as preparing them to live in society. According to Chaney [1], speaking is the process of building and sharing meaning through the use of verbal and nonverbal symbol, in a variety of context. Huebner states that speaking is a skill used by someone 
in daily life communication whether at school [10]. The skill is acquired by much repetition; it is primarily a neuromuscular and not an intellectual process.

In the context of speaking learning, social skill will help students to share information so that they do social interaction unconsciously. The development of cooperative learning must be directed to the development of students' social for joining the community [24]. One of social skill based-methods is Group Investigation (GI). By GI cooperative learning model, active interaction will happen among students in terms of physical, intellectual, and emotional [25]. Cooperative learning refers to a learning which based on a small-group approach in teaching that holds students accountable for both individual and group achievement [12][13]. Slavin formulates cooperative learning as follows [22]: Cooperative learning refers to a variety of teaching methods in which students work in small groups to help one another learn academic content. In cooperative classrooms, students are expected to help each other, to discuss and argue with each other, to assess each other's current knowledge and fill in gaps in each other understands.

Cooperative learning has many types of models. At least, there are 16 types of cooperative learning in developed countries [17];[16]. This research focused on the development of Group Investigation-type cooperative learning which then further developed by referring to the learning needs. This research is about speaking course with discussion topic of unemployment and employment. Eggen \& Kauchak [7] define Group Investigation as a cooperative learning strategy which puts students in groups to make investigation on certain topics. GI was developed by Herbert Thelen as an effort to combine teaching strategy which orientates to the development of academic study. Joyce and Weil [16] gives additional information that GI learning model developed by Thelen came from the insights of John Dewey and Michaelis who stated that education in democratic society should teach democracy directly. Mun, Ngoh \& Lian conveys that GI learning model was developed by Sharan and Sharen in 1970 in Israel Sharan \& Sharan [21]. Meanwhile, Mun, Ngoh \& Lian argue that GI learning model philosophically moves from constructivism paradigm [25]. Learning according to constructivist is the result of cognitive construction through somebody's activity. It emphasizes on the opinion that our knowledge is developed by ourselves [22]. Related to social skill, the goal of social skill in teaching speaking is to make students be able to interact with their peers so that they can accomplish and enjoy their work together.

A pre-survey has been conducted to the first semester students of Indonesian Language and Literature Education Department at a private university in Indonesia, IKIP PGRI Bojonegoro. Through observation and interview, the recent condition of teaching speaking can be noticed. Indicators of social skill were categorized not good enough as the percentage of each indicator showed 35\%. The criteria were categorized based on Mun et.al [25] who stated that there are three percentage scores of social skill i.e. (1) $0 \%-40 \%$ classified as not good enough, (2) $41 \%$ $70 \%$ classified as good enough, (3) $71 \%-100 \%$ classified as good. Social skill is defined as a very important competence owned by everybody including students in keeping positive social relationship with family, peers, society, and wider relation [18]. Lecturers hold pivotal roles to improve social skill of students. Some research findings show that cooperative learning model is very helpful to lecturers and students as follows: (1) Slavin (1995) found 86\% students taught by cooperative learning model has higher academic achievement than those taught by other learning models [22]; (2) Mun et.al reported that students taught by cooperative learning model performed better than those taught by competition system in which ratio was $74 \%: 26 \%$ [25]; (3) Stahl (1996) found that cooperative learning model more arouses the students' solidarity and transparency among students [24]. Stahl's research demonstrated that cooperative learning model supports the goal achievement and education characters. 
A learning model is considered effective in improving social skill of students [2]. Since not all learning models can improve students' social skill, the researcher chose cooperative learning model as the alternative to improve social skill of students. Before development, cooperative learning model of Group Investigations is a learning process which is carried out cooperatively or in group where students try to find information (thoughts, opinion, solution data, and so forth) related to learning from various sources. At the end, students evaluate and synthesize the information truths which have been gathered together. In this learning model, students are expected to think autonomously. Slavin found that in Group Investigation, students work in six phases namely (1) Grouping, (2) Planning, (3) Investigating, (4) Organizing, (5) Presenting, and (6) Evaluating [23]. Cooperative learning model of Group Investigations is then developed in which students must share information about the topic given by the lecturer so that the subtheme of new idea is obtained. Every group is obliged to find solution to overcome the problem. After having a plan, investigation is started in which every group presents its findings. All members of each group must give opinion and answer all questions from other groups equally. Authentic assessment is the type of evaluation used in this research as it is in line with the curriculum of Indonesian Language and Literature Education Department. The authentic assessment is in the form of assessment sheet of skill which must be filled during the teaching and learning process. Meanwhile, the multiple choices test is used to know the differences between pre and post learning activity.

This research aimed at analyzing two main problems as follows: (1) Developing a learning model of Beach Ball Group Investigations to improve students' social skill; (2) Analyzing the effectiveness of a learning model of Beach Ball Group Investigations during the speaking course taken by the first semester students at Indonesian Language and Literature Education Department of IKIP PGRI Bojonegoro.

\section{METHOD}

This is Research and Development (R \& D) design. It consists of 5 main steps as follows: 1) analyzing the product wanted to develop, 2) developing initial product, 3) expert validation and revision, 4) small scale field trial and product revision, and 5) big scale field trial and final product. The first step is analyzing the product wanted to develop by preliminary study and information gathering. The second step is developing initial product by making a plan resulted from preliminary study and previous product. The third-fifth steps belong to the phases of development design of Dick and Carey. There were two classes as the research samples, class IA as the experimental class, while class IB as the control class. The data were collected by questionnaire, observation, and multiple choices. They were analyzed through T-test and $n$-gain to know the effectiveness of product being developed by researcher.

\section{RESULT AND DISCUSSION}

This Research and Development design answered two research questions. First, it developed BBGI cooperative learning model to improve social skill. Second, it investigated the effectiveness of BBGI during speaking course. The product resulted from this research is BBGI cooperative learning model applied in the speaking course of the first semester students at Department of Indonesian Language and Literature. This BBGI is more creative and innovative as it gives students opportunities to think creatively and to speak actively during the learning process. The implementation of BBGI is expected to arouse students sharing information, interacting with peers and lecturer, and expressing ideas and thoughts on the teaching materials. 
The development of cooperative learning model of BBGI developed in this research has some phases as follows: (1) Lecturer tells the learning objectives and shows the main issue of workforce; (2) Lecturer gives pre-test to students; (3) Students discuss and express opinion on issues related to workforce while taking some notes; (4) Students categorize some themes and make groups (1 group consists of 5 students); (5) Students join their groups and make a plan of investigations; (6) Students discuss their group theme and choose relevant sources to support their investigations; (7) Each student finds the answer or solution on the topic problems from many sources. After getting the answers, they return to their group and interchange their thoughts as well as discuss the results of investigations; (8) Students make a discussion report and present it; (9) Students are given 5 colorful balls signaling the opportunity to speak. When the student wants to ask a question, she/he must put out one ball and so does the answerer. When all balls have been put out, each group member has same opportunity to both ask and answer; (10) Students and lecturer conclude the discussion result; (11) Students do posttest as cognitive evaluation.

There are some aspects distinguishing the recent cooperative learning model of Group Investigations from the previous one with problem-based learning. Table 1 describes the differences between the previous and the recent learning model of Group Investigations.

Table 1. The Differences between Previous and Recent Group Investigations.

\begin{tabular}{lll}
\hline No & \multicolumn{1}{c}{ Previous Group Investigations } & \multicolumn{1}{c}{ Recent Group Investigations } \\
\hline 1. & $\begin{array}{l}\text { At the beginning of learning process, the } \\
\text { lecturer did not tell the goal of learning to the } \\
\text { students. }\end{array}$ & $\begin{array}{l}\text { At the beginning of learning process, the } \\
\text { lecturer delivers the goal of learning and shows } \\
\text { the main issue. }\end{array}$ \\
\hline 2. & $\begin{array}{l}\text { The student's opportunity to speak was } \\
\text { unequal. }\end{array}$ & The student's opportunity to speak is equal. \\
\hline 3. & $\begin{array}{l}\text { There was no explanation on the phases to } \\
\text { conduct this learning model. }\end{array}$ & $\begin{array}{l}\text { There is explanation on the phases to conduct } \\
\text { this learning model. }\end{array}$ \\
\hline 4. & $\begin{array}{l}\text { No guidance book on how to implement this } \\
\text { learning model. }\end{array}$ & $\begin{array}{l}\text { There is a guidance book on how to implement } \\
\text { this learning model. }\end{array}$ \\
\hline 5. & $\begin{array}{l}\text { This learning model was implemented without } \\
\text { Beach Ball. }\end{array}$ & $\begin{array}{l}\text { This learning model is implemented with Beach } \\
\text { Ball. }\end{array}$ \\
\hline 6. & Cognitive evaluation. & $\begin{array}{l}\text { Authentic assessment by observation sheet on } \\
\text { social skill filled during the learning process and } \\
\text { multiple choices of cognitive test. }\end{array}$ \\
\hline
\end{tabular}

Beach Ball or colorful small ball functions as the medium for cooperative learning model of Group Investigations signaling the students the opportunity to speak. Every group member gets one ball. When a student wants to argue, she/he must put out the ball and she/he cannot convey her/his opinion before the other group members put out their ball but she/he may help the other members to state opinion. Beach Ball prevents certain students to dominate the learning process. In other words, it provides the equal opportunity for students to speak. By Beach Ball, every student automatically gets only 1 opportunity to deliver opinion. Thus, Beach Ball and Group Investigations can be modified and combined into one game method which then implemented in the learning process. It is expected that the cooperative learning model of Beach Ball Group Investigations can improve students' social skill.

The learning theory underlining the development of cooperative learning model of BBGI is behaviorism learning theory. It argues that students will achieve the learning goal if they are given stimulus. By having BBGI cooperative learning model, the students are aroused to speak and improve their social skill as during the learning process, they become more active and have 
same opportunity to convey opinion as well as to answer questions. The stimulus was the learning model itself which has been adjusted to the indicators of social skill [18]. The stimulus and response in this learning model can create positive behavior or habit if they are repeated. Sani explains that learning belongs to behavior changing which can be observed, measured, and assessed concretely [20]. This theory uses the correlation between stimulus-response and places students as passive individuals. If stimulus and response are repeated, they can be a habit. Certain responses and behavior are obtained through training or habituation method.

The second theory underlining this learning model is cognitivist theory. The implication of cognitivist development theory in BBGI cooperative learning model is that lecturer must help students in developing their knowledge. The final result of learning in this research is concept acquisition resulted from interaction during the learning process as well as the effects of social skill. Meanwhile, the third theory of this learning model is constructivism theory which argues that learning is a process, not a result. Students are triggered to do investigations to naturally develop their curiosity. The assessment of learning outcomes is emphasized on students' performance and understanding. The constructivism theory states that students must find information by themselves and transform complex information, check new information with old regulation, and revise it if there is a mismatch regulation. Based on the result of formative evaluation, BBGI cooperative learning model was feasible to use. Therefore, based on some suggestions, formative evaluation of the fourth phase was conducted by field trial in the classroom to the students of a private university, IKIP PGRI Bojonegoro, Indonesia.

The field trial was conducted by comparing the experimental class with BBGI learning model and control class with Problem-Based learning model. The trial was given to 33 students of class IA as the experimental class and 30 students of class IB as the control class. The learning process by BBGI underwent actively in which students were challenged to accomplish their assignment and improve their social skill. This research used scientific approach as all learning processes were designed to make students active in constructing concept, law or principles through some phases of observation (to identify or find problems), problem statement, hypothesis formulation, data collection by various techniques, data analysis, conclusion drawing, and new concept, law or principles communication.The objective of teaching spoken language is the development of the ability to interact suc cessfully in that language [11]. It means that teaching speaking can develop the abilities to think critically, express ideas/thoughts, solve problems, and have social skill (building commitment and awareness on humanity values) through interaction. Besides, the teaching of speaking skill aims at improving the ability to compete and cooperate with people in heterogeneous society both in national and international scales.

The speaking course with the discussion theme of unemployment and employment by using BBGI and problem-based learning was intended for improving social skill of students so that they can develop their personality in school and society. In this context, personality development means that after undergoing a learning process, there must be development and adjustment to the betterment of student's behavior. BBGI cooperative learning model demands students to be more active and skillful during the learning process as well as to explore and behave based on the social skill. The effectiveness of BBGI cooperative learning model was tested by t-test and n-gain (differences between pretest-posttest). Tcalculation was greater than ttable by $2.660>1.998$ which meant that social skill resulted from experimental class taught by BBGI was better than that from control class taught by problem-based learning. The average score of social skill with BBGI was $76.52 \%$ which led to good criterion based on Mun et. al classification ( $[25]$. The difference between pretest-posttest was $71.73 \%$ for experimental class and $66.56 \%$ for control class. Based on classification table of n-gain according to Hake 
(1999)[8], n-gain of experimental class was high by $71.73 \geq 70.00$. Thus, it could be concluded that BBGI was effective in improving social skill of students.

In detail, there are four dimensions with 8 indicators used by the researcher to measure social skill. They are: 1) dimension of interaction skill with the indicator of ability to share information, 2) dimension of communication skill with the indicators of abilities to listen and speak in turn-taking as well as to convince others to argue, 3) dimension of team/group building skill with the indicators of abilities to accommodate other argument and to cooperate with other people, 4) dimension of problem solving skill with the indicators of controlling oneself, finding solution through discussion, and respecting different opinions. Dimension and indicator of social skill which has been a habit in this research was dimension of team building and indicator of cooperation. Theoretically, BBGI cooperative learning model was statistically effective as proven by tcalculation $>$ ttable which meant that social skill in experimental class taught by BBGI was better than control class taught by problem-based learning.

The result of this research is in line with the one done by Salako, et al entitled the Effects of Cooperative Learning toward knowledge and attitude of students on the concept of multicultural education in social science [19]. The research result showed that social skill was not only developed by learning materials but also by method, media, and learning model. Effective method and model which can improve social skill is cooperative learning model. This research is different from the previous one as it aimed at improving social skill. The result of this research was similar with the one carried out [9];[3];[4]; [6] who stated that cooperative learning model is very effective in improving and developing the process of teaching and learning on speaking course as well as increasing passion and academic achievement of students. This learning model has specific features with the teaching of speaking. It influenced not only to learning outcomes but also to attitude, value, moral, and social skill used in the community [26].

\section{CONCLUSION}

The product resulted from this research is a cooperative learning model of Beach Ball Group Investigations (BBGI) which can improve social skill of students. The effectiveness of BBGI cooperative learning model was tested by t-test and differences between pretest-posttest scores (n-gain). $\mathrm{T}_{\text {calculation }}$ was greater than table by $2.660>1.998$. The average experimental social skill by BBGI cooperative learning model was $76.52 \%$ and this percentage of social skill was categorized as good according to the criteria of Mun et.al [25]. Meanwhile, the n-gain between pretest and posttest was $71.73 \%$ and it was classified as high by $71.73 \geq 70.00$. In conclusion, BBGI cooperative learning model was effective in improving student's social skill.

\section{REFERENCES}

[1] A.L. Chaney, Teaching Oral Communication. In: Grandes K-8. Boston: Allyn and Bacon, 1998.

[2] A. Darmuki at al. Evaluating Information-Processing-Based Learning Cooperative Model on Speaking Skill Course. Journal of Language Teaching and Reasearch. Vol. 8, No. 1, pp. 44-51, 2017.

[3] A. Darmuki, Andayani, J. Nurkamto, K. Saddhono. "The Development and Evaluation of Speaking Learning Model by Cooperative Approach". International Journal of Instruction. 11(2) pp. 115-128, 2018.

[4] A. Darmuki, Andayani, J. Nurkamto, K. Saddhono. "Cooperative, Synectics, and CTL Learning Models toward Speaking Ability Viewed from Student's Motivation". 
International Conference on Intellectuals' Global Responsibility (ICIGR). 125, 75-79, 2018.

[6] A. Darmuki, N. A. Hidayati. An Investigation of The Cooperative Learning Using Audio Visual Media in Speaking Skill Subject. ICSTI. 121-126, 2019.

[7] P. Eggen \& D. Kauchak. Strategi dan Model Pembelajaran Mengajar Konten dan K eterampilan Berfikir. Jakarta: Indeks, 2012.

[8] H. R. Richard. "Analyzing Change/Gain Score". American Educational Research Association's Division Measurement and Research Methodology. http://Lists.Asu.Edu/Egi-Bin. 1999.

[9] Hengki et. al. "The Effectiveness of Cooperative Learning-Strategy through English Village for Teaching Speaking Skill". Journal of Language Teaching and Reasearch. Vol. 8, No. 2, pp. 306-312, 2017.

[10] T. Huebner. Audio Visual Technique in Teaching Foreign Language. New York: Cambridge University Press, 1960.

[11] A. Hughes. Testing for Language Teacher. Second Edition. New York: Cambridge University Press, 2003.

[12] D. W. Johnson \& R.T. Johnson. "Social Interdependence Theory and Cooperative Learning: The Teachers ${ }^{e e}$ Role. In R. M. Gellis., A.F. Ashman \& J. Tarwel. (eds.), The Teacher's Role in Implementing Cooperative Learning in The Classroom, pp. 9-38. New York: Springer, 2008.

[13] D. W. Johnson, R. T. Johnson, \& E. J. Holubec. Cooperation in the classroom. Edina, MN: Interaction Book Company, 2008.

[14] D.W. Johnson. Reaching Out: Interpersonal Effectiveness and Self-Actualization. 9th ed. Boston: Pearson, 2006.

[15] E. Johnson. Contextual Teaching and Learning. Bandung: MLC, 2007.

[16] Joice \& Weil. Model of Teaching. Eight Edition. USA: Pearson Education, Inc, 2009.

[17] A. Lie. Cooprative Learning: Mempraktikkan Cooperative Learning di Ruang-Ruang Kelas. Jakarta: Grasindo, 2007.

[18] E. Maryani. Pengembangan Program Pembelajaran IPS Untuk Peningkatan Keterampilan Sosial. Bandung: Alfabeta, 2011.

[19] Salako et al. "Effects of Cooperative Learning on Junior Secondary School Students' Knowledge and Attitudes to Multicultural Education Concepts in Social Studies". Education, Vol. 133, No. 3, pp. 303-309, 2013.

[20] A. R. Sani. Inovasi Pembelajaran. Jakarta: Bumi Aksara, 2013.

[21] S. Sharan \& Y. Sharan. Expanding cooperative learning through group investigation, Colchester, VT: Teachers College Press, 1992.

[22] R. E. Slavin. Co-operative learning: Theory, research, and practice. (2nd edition), Boston: Allyn and Bacon, 1995.

[23] R.E. Slavin. Cooperative Learning: Teori, Riset, Dan Praktik. Bandung: Penerbit Nusa Media, 2005.

[24] R.J. Stahl. Cooperative Learning in Social Studies. Handbook for Teacher. USA: Kane Publishing Service Inc., 1996.

[25] F. Mun, K. Ngoh, \& S. Lian. Using Group Investigation for Chemistry in Teacher Education. Asia-Pacific Forum on Science Learning and Teaching, Vol. 5, No. 1, pp. 1-6, 2004.

[26] K. Saddhono and M. Rohmadi, "A Sociolinguistics Study on the Use of the Javanese Language in the Learning Process in Primary Schools in Surakarta, Central Java, Indonesia." Int. Edu. Stu., vol. 7 no.6 pp 25-30, 2014 
